\title{
The Use
}

\section{and Development}

\section{of the Xinkan Languages}

Published through the Recovering Languages and Literacies of the Americas initiative, supported by the Andrew W. Mellon Foundation 


\section{The Use and Development of the Xinkan Languages}

Chris Rogers 
This book is a part of the Recovering Languages and Literacies of the Americas publication initiative, funded by a grant from the Andrew W. Mellon Foundation.

\section{RTS RECOVERING \\ GLS I XNGUAGES\&LITERACIES \\ LANGUAGES\&LITERACIES
OF THE AMERICAS}

Copyright (c) 2016 by the University of Texas Press

All rights reserved

Printed in the United States of America

First edition, 2016

Requests for permission to reproduce material from this work

should be sent to:

Permissions

University of Texas Press

P.O. Box 7819

Austin, TX 78713-7819

http://utpress.utexas.edu/index.php/rp-form

(2) The paper used in this book meets the minimum requirements

of ANSI/NISO Z39.48-1992 (R1997) (Permanence of Paper).

Library of Congress Cataloging-in-Publication Data

Rogers, Chris, 1977- author.

The use and development of the Xinkan languages / Chris Rogers. - First edition.

pages $\mathrm{cm}-$ (Recovering languages and literacies of the Americas Mellon

Foundation Initiative)

Includes bibliographical references and index.

ISBN 978-1-4773-0831-8 (cloth)

ISBN 978-1-4773-0832-5 (pbk.)

ISBN 978-1-4773-0833-2 (library e-book)

ISBN 978-1-4773-0834-9 (non-library e-book)

1. Xinca language-Grammar, Historical. 2. Extinct languages-Guatemala.

3. Indians of South America-Guatemala-Languages. 4. Guatemala-Languages.

I. Title. II. Series: Recovering languages and literacies of the Americas.

PM4498.X31R64 2016

$497^{\prime} \cdot 9-\mathrm{dc} 23$ 
This grammar is dedicated to the Xinkan community of Cuatemala and especially to the last speakers of these languages and those involved in efforts toward language revitalization. 
THIS PAGE INTENTIONALLY LEFT BLANK 